\title{
Activity spaces, biographies, social networks and their welfare gains and externalities Some hypotheses and empirical results
}

\section{Working Paper}

Author(s):

Axhausen, Kay W. (1)

Publication date:

2005-06

\section{Permanent link:}

https://doi.org/10.3929/ethz-b-000123201

\section{Rights / license:}

In Copyright - Non-Commercial Use Permitted

\section{Originally published in:}

Arbeitsberichte Verkehrs- und Raumplanung 290 


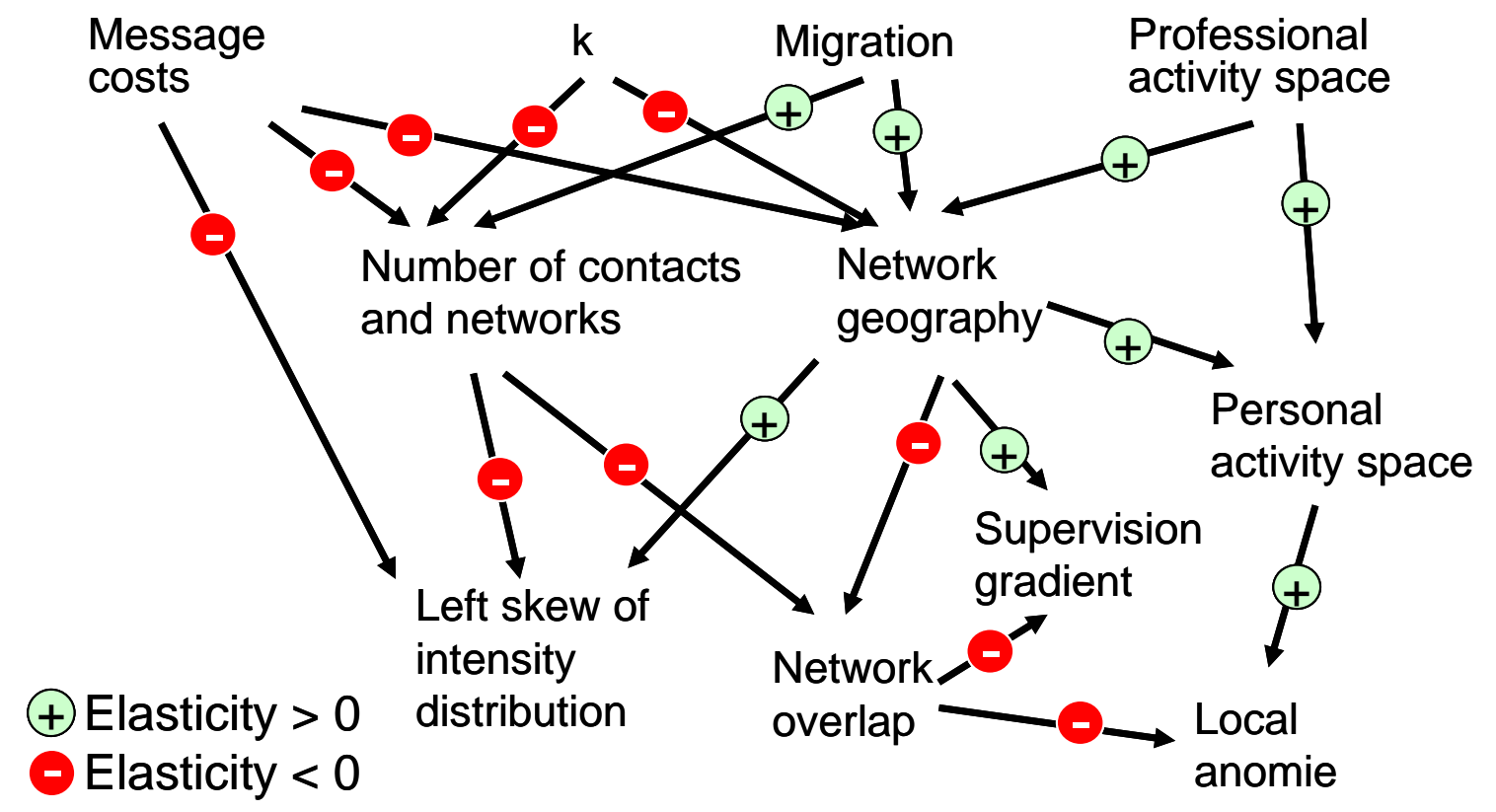

Paper for the PROCESSUS Colloquium, Toronto, June 2005

Activity spaces, biographies, social networks and their welfare gains and externalities: Some hypotheses and empirical results

KW Axhausen

Arbeitsbericht Verkehrs- und Raumplanung 290 
Arbeitsbericht Verkehrs- und Raumplanung

\title{
Aktivitätenräume, Biographien, soziale Netz, Wohlfahrts- gewinne, soziale Externalitäten: Hypothesen und Ergebnis- se
}

\author{
KW Axhausen \\ IVT \\ ETH \\ CH - 8093 Zürich
}

Telefon: +41-1-633 3943

Telefax: +41-1-633 1057

axhausen@ivt.baug.ethz.ch

June 2005

\section{Kurzfassung}

Dieser Aufsatz diskutiert die Wirkung der zeitlich schrumpfenden Welt auf die Strukturen und Geographien unserer sozialen Netze durch eine Gruppe von Hypothesen. Diese Hypothesen warden eingebettet in ein übergeordnetes Modell der Dynamik von Aktivitätenräumen und Gütermärkten.

Der Aufsatz endet mit der Skizze eines Forschungsprogramms, dass diese Hypothesen testen kann.

\section{Schlagworte}

Aktivitätenräume, Mobilitätsbiographien, Soziale Netze, Verkehrsverhalten

\section{Zitierungsvorschlag}

K.W. Axhausen (2005) Activity spaces, biographies, social networks and their welfare gains and externalities: Some hypotheses and empirical results, Arbeitsbericht Verkehrs- und Raumplanung, 290, IVT, ETH Zürich, Zürich. 
Working paper

\title{
Activity spaces, biographies, social networks and their wel- fare gains and externalities: Some hypotheses and empiri- cal results
}

\author{
KW Axhausen \\ IVT \\ ETH \\ CH - 8093 Zürich \\ Telephone: +41-1-633 3943 \\ Telefax: +41-1-633 1057 \\ axhausen@ivt.baug.ethz.ch
}

June 2005

\section{Abstract}

The repeated interactions and exchanges in formal and informal networks, e.g. family, firms, associations, friendship circles, regulars of a bar, are central to our daily life. There is no reason to assume, that the geography of the members of the networks, to which one belongs, has not been affected by the seminal drop in transport and telecommunication costs since 1950 . The paper will develop a conceptualisation of the dynamics of the interaction between the geographies of the social networks and of activity space growth. Against this background, more detailed, testable hypotheses about the change of the geographies, of the contact intensity distributions and numbers of contacts will be derived. The final section will discuss the impact of the hypotheses, if found to be true, on both transport modelling and transport policy. Key expected effects are indeed increases in the human activity spaces, human welfare, but combined with a loss of local trusts, i.e. a localised anomie.

\section{Keywords}

Social network, activity space, mobility biography, travel behaviour

\section{Preferred citation style}

K.W. Axhausen (2005) Activity spaces, biographies, social networks and their welfare gains and externalities: Some hypotheses and empirical results, Arbeitsbericht Verkehrs- und Raumplanung, 290, IVT, ETH Zürich, Zürich. 


\section{A small world}

The literatures on urban sprawl (see e.g. Axhausen, 2000 for a review), or globalisation (e.g. Friedman, 2005 or Taylor, 2004) take today's historically low generalised costs of travel either as given, or see it as something surprising. Neither attitude is helpful, if one wants to understand the social impact of this seminal change and the related changes in travel behaviour. The investment in transport infrastructures and in the rolling stock exploiting their possibilities is a necessary part of the modernisation and industrialisation of first the North-Atlantic societies and today the world (See Axhausen, 2005 for the argument). The purpose of this paper is not macro-sociological, but micro-sociological and will therefore not explore the links between market size, productivity growth and real incomes or between generalised cost of transport, food availability and population growth (see Sen, 1983). It wants to explore a set of linked hypotheses about activity space as the result of the structure and geography of a traveller's social network. It should be pointed out that these hypotheses should be taken as the starting points for yet to be undertaken empirical work. The evidence, which I can adduce here, is based on very small samples, incomplete, often from questions smuggled into other surveys.

The accelerated shrinking of distance through infrastructure additions allowing ever increasing sustained speeds has now been going on for two hundred years (see Grübler, 1992 and 1998 for period since 1800, but Spufford, 2002 or de Vries and van der Woude, 1997 for earlier periods). Canals, pike roads, then the inter-urban and urban railways were the main investments during the $19^{\text {th }}$ century. These infrastructures lowered transport costs already very considerably, but for many travellers and much daily traffic this early motorisation remained irrelevant, as the vehicle costs remained too high relative to many incomes. The nickel - fares of late $19^{\text {th }}$ US local public transport and then the cheap and reliable car liberated the urban travellers from their dependence on their feet. Figure 1 illustrates this for post-war Switzerland using time-scaled maps (see Scherer, 2004 for the creation of the maps; Fröhlich and Axhausen, 2005 for network models employed). The maps, in which distances indicate travel time, show that the country has essentially been more than halved in size, which is even more important when one considers that the motorisation rate went from 31 for 1000 inhabitants in 1950 to 492 in 2000 (Widmer and Meister, 2005). While the costs for the usage of cars have stagnated during the last decades (Abay, 2000 for Switzerland and Rhode and Strumpf, 2003 for the USA), the quality adjusted purchase costs continue to decline, as shown in Figure 2. The even more dramatic drop in the costs of telecommunication (Figure 3 ) is in line with the 
developments in physical transport. Zero marginal cost local calls are becoming the rule worldwide; zero marginal cost long-distance calls are becoming available through voice-overIP technology (See for example www.skype.com).

Figure 1 Road travel time - scaled mapping of Switzerland (same scale for both year)

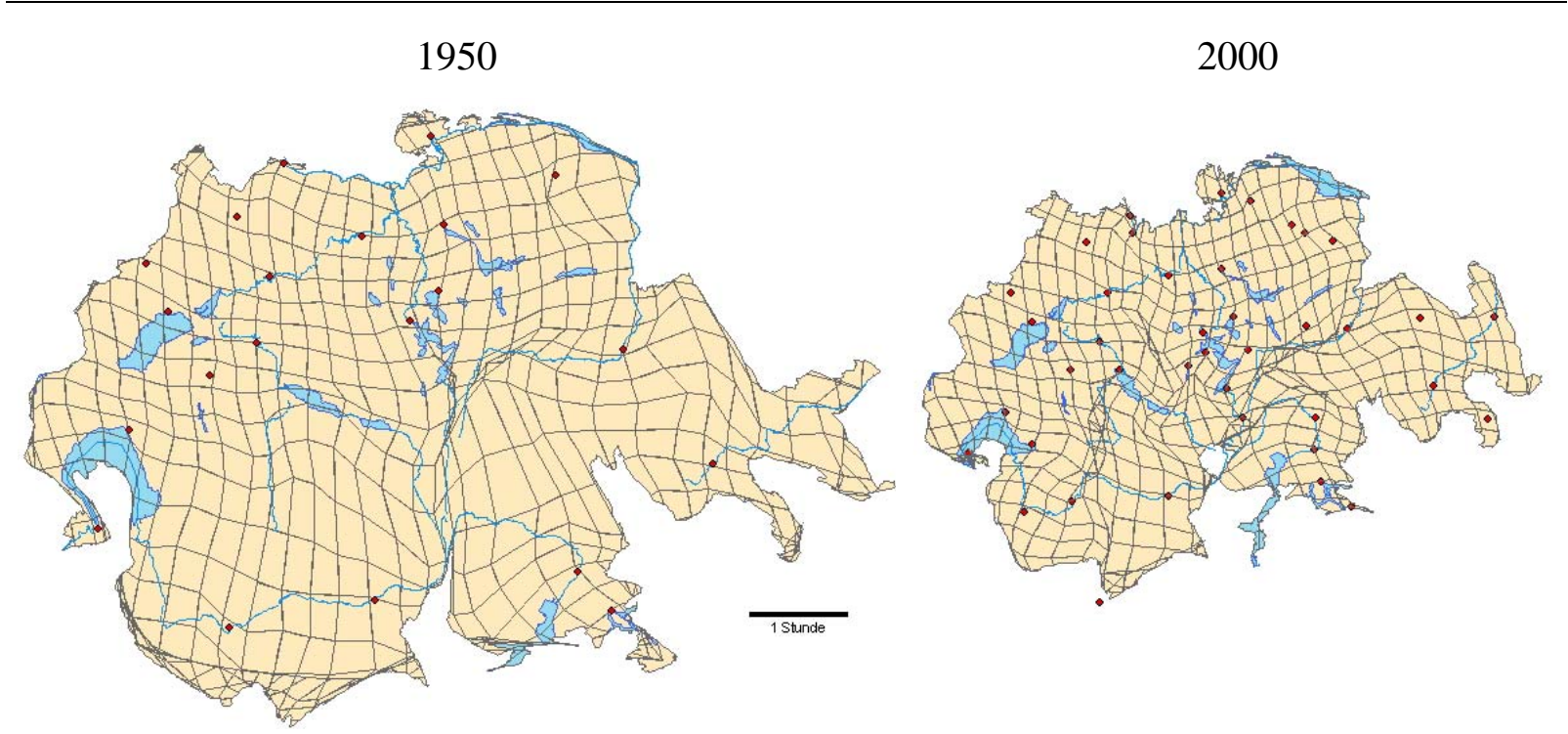

Maps: Scherer (2004) and later revisions

The impact of this small world or better cheap world in generalised cost terms, on the structure of the social networks of the travellers and their daily life will be discussed in the following section. The "small world” issue discussed since Milgram's initial paper (1967) in for example Travers and Milgram, 1969; Watts, 1999; Barabasi, 2002 or Dodds, Muhamad and Watts, 2002 will be left aside as an essentially academic exercise ${ }^{1}$. Structure means here not only the topography of the network (Wasserman and Faust, 1994), but also its geography. The topography describes in a link/node notation which persons in an environment are linked to the others. A unidirectional link exists if a certain minimum flow of resources can be observed over a defined period from one person to a certain other persons. The corresponding reverse link exists normally, but not necessarily, as well. The resources can be classified according to type, as for example money, labour, attention, social recognition, emotional support, time for a particular joint activity. It is assumed that the volume of flow across types, but also the breadth of the types involved is a measure of the strengths of the link. 
Figure 2 Quality adjusted 2004 purchase prices for private cars 1906 - 2004

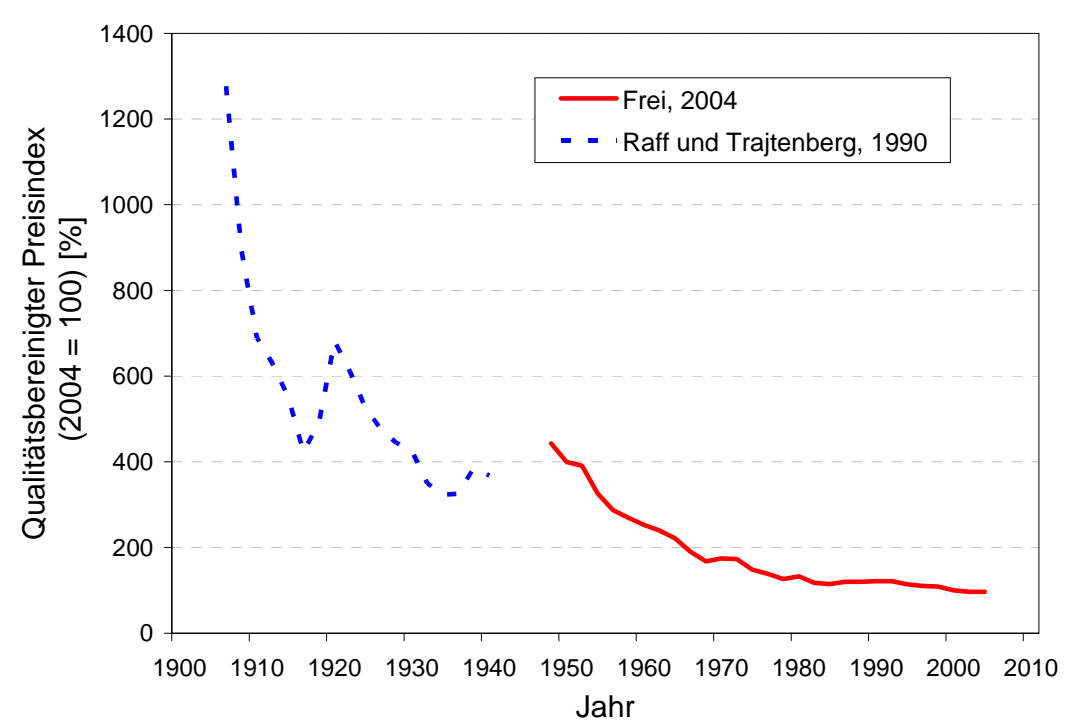

Data: Frei (2005) for Switzerland 1950 - 2004; Raff and Trajtenberg (1985) for the USA, $1906-1940$. The Swiss time series is very likely underestimating the drop in the quality adjusted prices since 1985, as appropriate time series data on vehicle electronics were not available for analysis.

Figure 3 Real costs of US interstate and international telephone calls 1930 - 2000

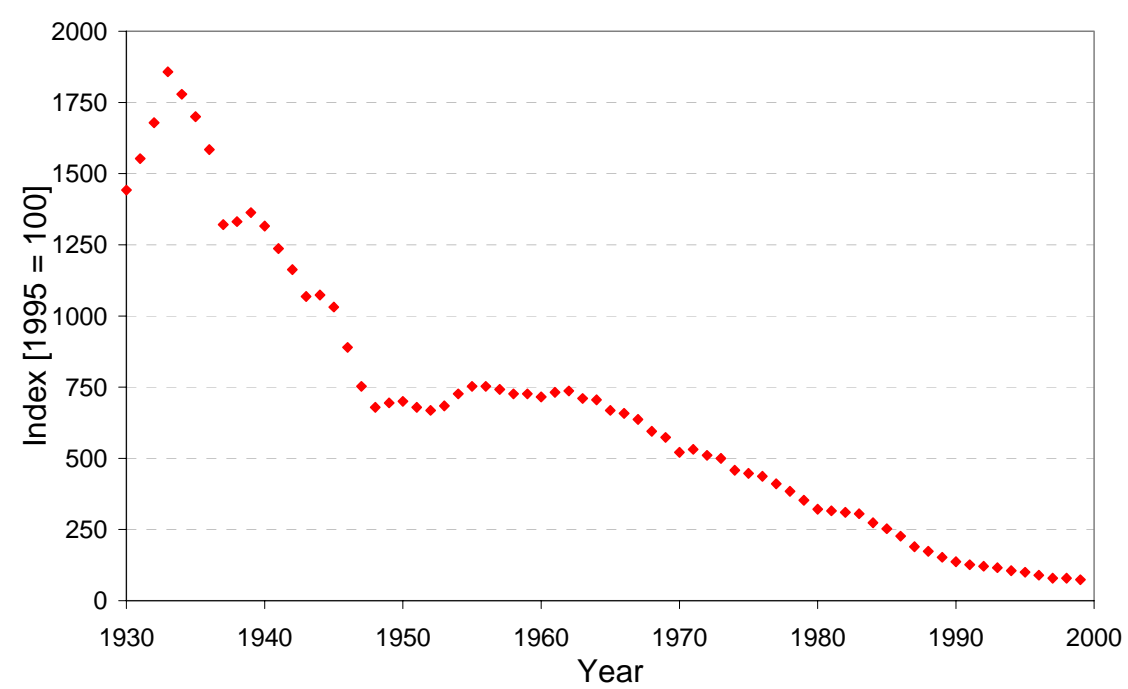

Adapted from FCC, 2001

${ }^{1}$ The enormous attrition rates of the „small world“ experiment reported in Dodds, Muhamad and Watts, 2002 raise the question, if and if so, how quickly information will spread in such networks (See Huberman and Adamic, 2005 for a review of this issue). 
The relative strengths of the flows between a pair of persons can be interpreted as a measure of their relative power. The analysis of the management of these links in the pursuit of daily life, medium-term projects and life goals is a core subject of micro-sociological enquiry (See for example Goffman, 1959; Fehr and Fischbacher, 2004 or Fehr and Gächter, 2000; Grieco, 1996 for discussions of such central topics as management of self, fairness and reciprocity, local trust and household resource management).

The social science literature on social networks (e.g. Wellman, 1996; 1999a, b, 2000, 2001; Moore and Brown, 1970; Hampton and Wellman, 2001, 2003; Haythornswaite and Wellman, 1998; Freeman, 2000; Burt, 2000b and 2001) tends to ignore or aggregate space, so that the information about the relative locations of the actors and therefore their travel and communication costs is lost. This geography of the relative locations and the associated costs of travel and communication is the focus of the interest here. The assumption is that effective changes in the geography of costs and locations will impact both travel and social patterns profoundly. The geography of the members of the traveller's social networks together with the geography of the relevant activity locations determines the amount and style of travel. Just consider that most leisure travel, which now makes up the relative majority of all trips in Switzerland for example, involves travelling with and meeting others. See Figure 4 for mean number of household and non-household members travelling with the 250 respondents over a 6-week reporting period (Axhausen, Löchl, Schlich, Buhl and Widmer, 2005 describe the survey in detail). This implies that the locations will reflect the joint preferences of the group, potentially living at dispersed locations

For the individual any system-wide change runs in parallel with his/her personal development. His/her mobility biography of intertwined changes in home, education and work locations and availability, ownership of mobility tools (licences, cycles, motorcycles, cars, season tickets and public transport discount cars) and social networks will reflect those changes, but also modulate it according to personal needs (for an example emphasizing network geographies see Blinde and Schlich, 2002). In the interpretation of empirical results one should keep this in mind.

This double understanding of structure creates a problem in the use of the words: dense and density, which can refer to both the spatial density (number of objects per area), as well as to the density of linkage in a social network (number of links originating from a person per per- 
son). To avoid confusion, this paper will use the opposites "loose, tight" to describe the patterns of linkage, while the pair "sparse, dense” will refer to the spatial density.

In principle one cannot divide the total network linking humans at any one time, ignoring socially or spatially isolated communities, such as the highlanders of Papua New Guinea or Easter Islanders, for the time being. Still, in everyday practise persons will treat their total network, as if it divides into separate networks based on their common activities, their genesis, their common awareness of each others, their permissible questions and demands, their solidarities.

The paper will be structured as follows. In the next section, it will discuss the problem of how to measure the size and spread of the social network geographies and of daily life in an efficient and parsimonious way, so that change or difference can be captured. The main section will propose and discuss the set of hypotheses. Finally the paper will summarize the hypotheses by embedding them in a simple model of personal resource allocation and by offering a research programme. 
Figure 4 Mean number of persons travelling with the respondents of the 2003 Thurgau sixweek travel diary survey by trip purpose

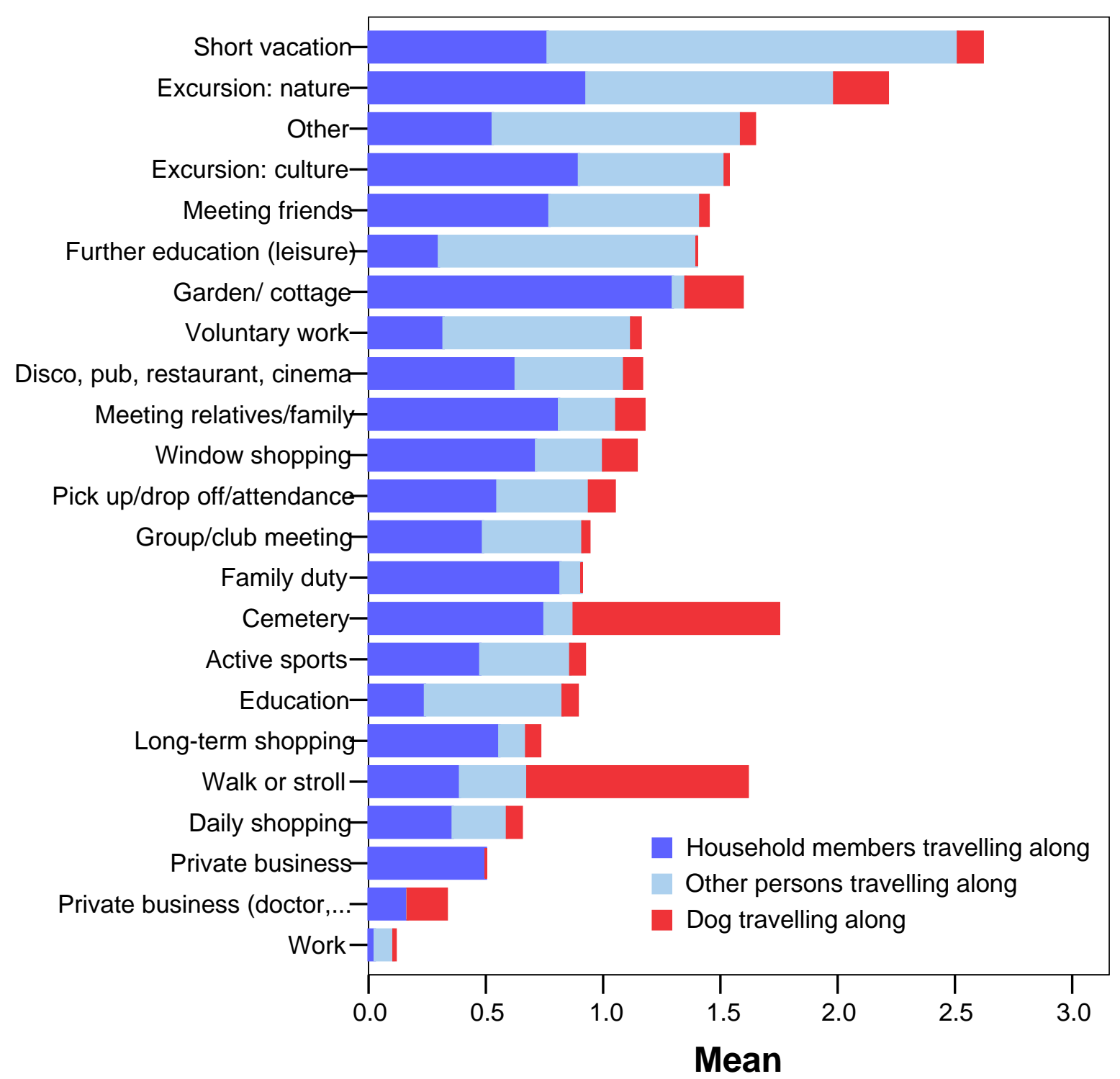

\section{Measuring the network geographies and activity spaces}

The main static elements of the geography of a social network are the home locations of its membership, while the dynamic elements of its activity space are the locations where some or all members meet. If the network is defined through joint association with an organisation, such as a firm, or club, then the seat of this organisation could be counted among the static 
elements of the geography. Given the range of networks and the increasing fluidity of their static elements, such as the workplace, it seems preferable not do so. Maps showing the locations of the homes or joint activities are very useful, but while the analyst can detect patterns quickly these patterns need to be reduced to a small set of indicators, which can compared between networks, traced over time and modelled. Schönfelder and Axhausen, 2003a, b suggest a series of such measures for individual activity spaces. The confidence ellipse, the twodimensional generalisation of the confidence interval, is the easiest to compute of the proposed measures. As a parametric approach (fixed geometrical form), it will overestimate the size of the geography, in particular, if one chooses a point other than the weighted mean of the locations as its centre. Still, they show that it is strongly correlated with more complex approaches, which seem therefore to be redundant. Figure 5 shows the home locations of the significant contacts of a person interviewed by Ohnmacht (2004), as part of an on-going study on travel, biographies and social networks in Zürich. It also shows the 95\% confidence ellipse around the mean home location of the life-course of the respondent. The ellipse captures both the spread and the orientation of the network geography. The ellipse seems therefore an appropriate measure for network work geographies in the first instance; especially given its ease of computation.

Figure 5 Example of an geography of the friendship network

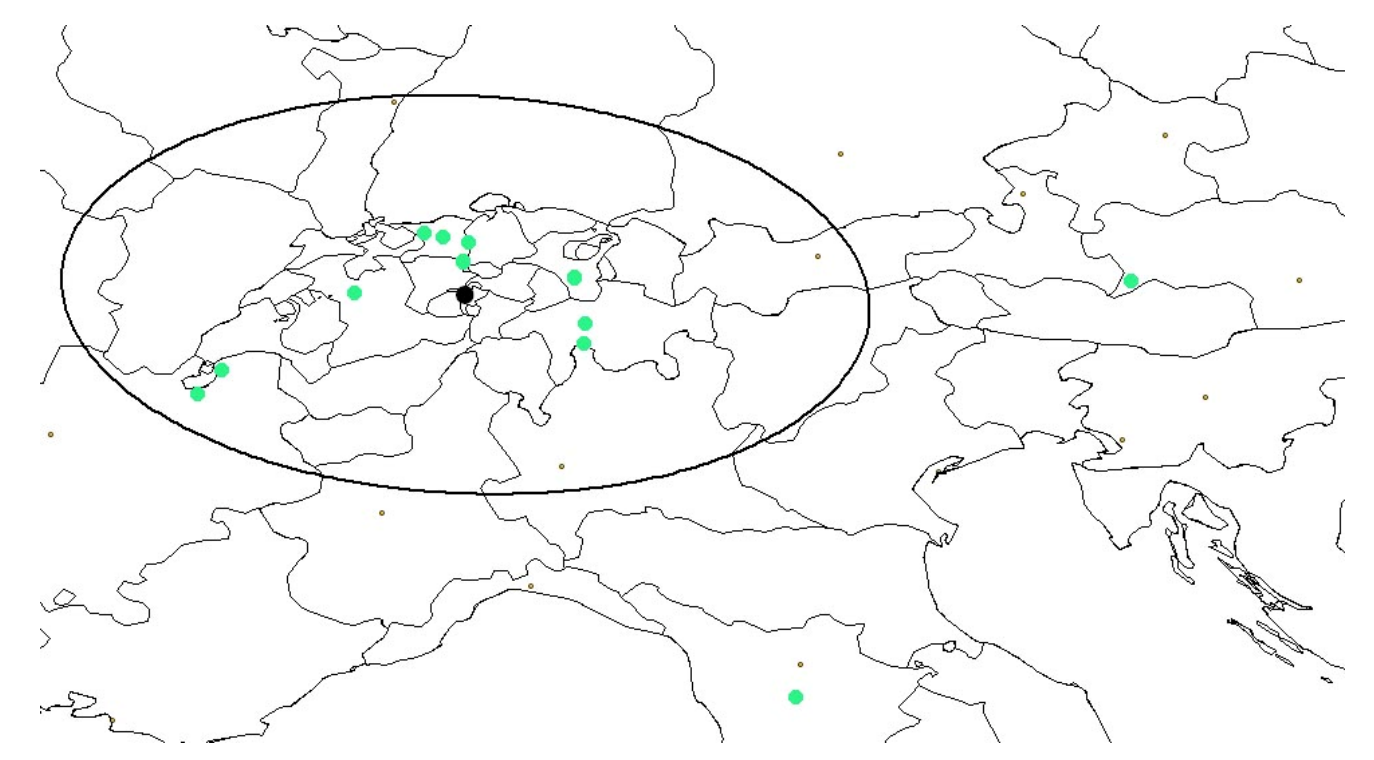

Source: Ohnmacht, 2004 (Person 4); 95\% confidence ellipse is calculated around the mean home location of the life course of the respondent.

The usefulness of this approach for the tracing of change is visible in Figure 6. Here the confidence ellipse is used to describe the in-commuter sheds of the ten largest Swiss cities. Their 
growth over the last three decades, but also the changes in their orientation become clearly visible.

Figure 6 In-commuter-sheds of the 10 largest Swiss cities since 1970

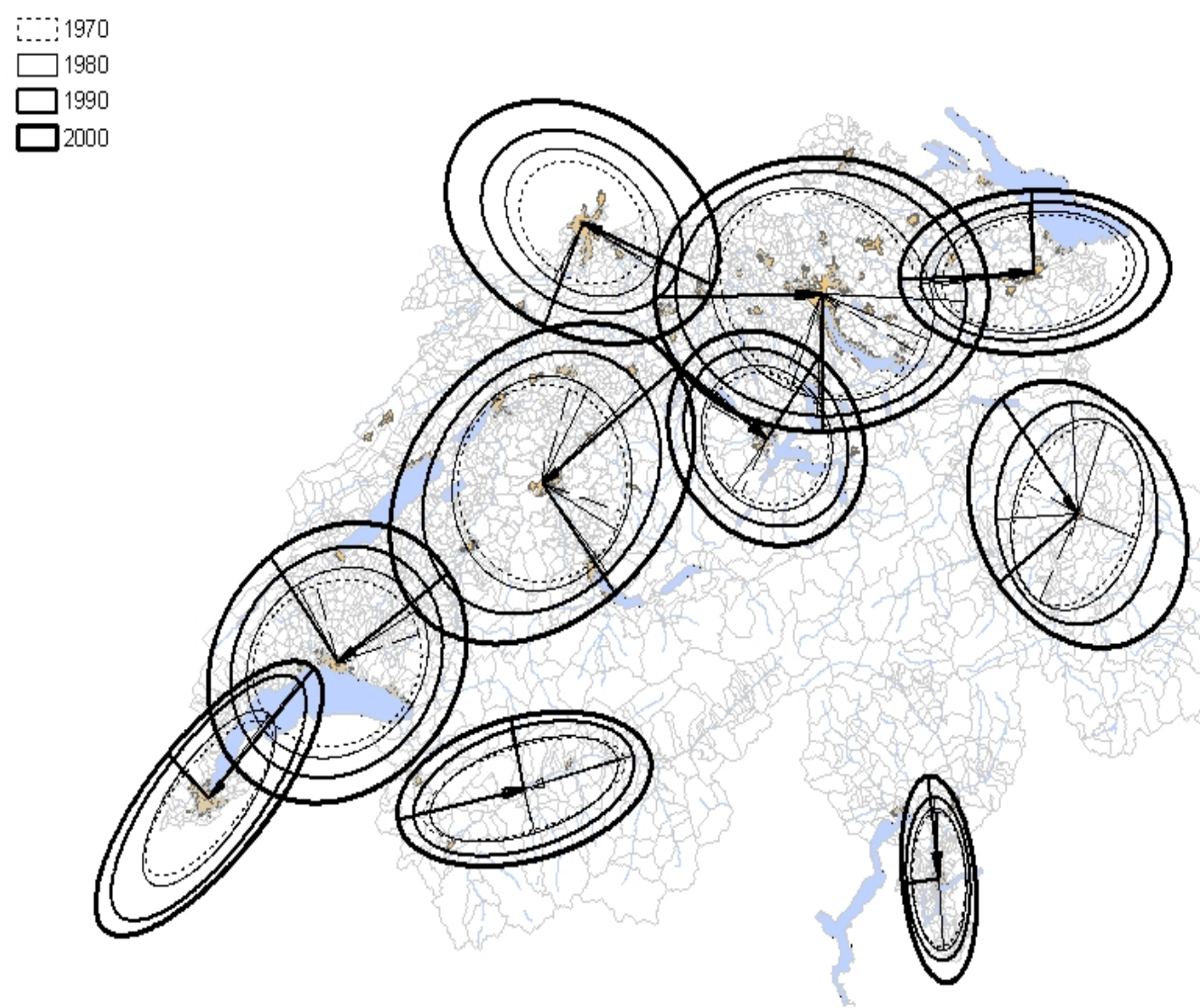

Adapted from Botte, 2003.

These two examples demonstrate that one can make useful statements about the size of a social network geography, which are based on the spread of the relevant locations. This is important, as the even simpler measures based on the distributions of the distances between the individual and its contacts, such as the mean or median, do not contain information about the spread of the locations.

\section{Hypotheses}

The hypotheses and their collaries will address in turn the size of network geographies, the number of contacts and networks, their structure and finally the expected impacts on travel behaviour and welfare. They are: 
[1] The size of the social network geography is inversely proportional to the generalised costs of travel and communication

[2] The number of contacts individuals maintain is inversely proportional to the generalised costs of travel and communication

[3] The probability of being linked to a member of one's network through multiple networks increases with the spatial density of one's contacts

[4] The distribution of effort on non-household members will become more left skewed as the spatial social network tightness decreases

[5] The knowledge about the contacts of contacts in a social network is proportional to the generalised costs of travel and communication

[6] The activity space of an individual is proportional to its social network geography

[7a] The size of the local activity space of an individual stabilises after an initial exploration.

[7b] The size of the total activity space will grow in line with the growth of social network geographies.

[8] The reliance on commercial or publicly funded personal services increases proportionally with the geography of social networks

[9] The welfare of the individuals should increase inversely proportional to the generalised costs of travel

The first hypothesis suggests that:

[1] The size of the social network geography is inversely proportional to the generalised costs of travel and communication

Individuals use decreases in generalised costs to meet and retain contacts living further away. It is well known that travellers adjust their travel distances in response to system improvements. See for example Cervero and Hansen, 2000 or Fröhlich, 2003 for evidence from models of induced demand or Schäfer and Victor, 2000; Zahavi and Talvitie, 1980 on the constant travel time budget hypothesis. These increased distances imply also social contacts at increasing distances given the importance of visiting friends, family and colleagues among all travel, which is borne out by the fact that the share of leisure and business trips increases with increasing trip distance.

A corollary of this hypothesis is that 
[1.1] social contacts should become more selective,

as persons can choose among a larger number of possible contacts available within the same generalised cost isoline. There is no need anymore to socialise with spatial neighbours. This is consistent with the generally observed trend to individualisation (Giddens, 1984 or Beck, 1986), which implies more specialised patterns of exchange and social matching. A further corollary is that

[1.2] the mobile phone increases social selectivity

by making it more difficult to meet persons without prior coordination, as persons are less likely to be reliably in certain places at certain times.

A third corollary is, that

[1.3] The spatial density of contacts falls with decreasing generalised costs of travel.

as the result of the first two suggestions.

The second hypothesis is:

[2] The number of contacts individuals maintain is inversely proportional to the generalised costs of travel and communication

As defined above, a social network link only exists if there is a certain volume of exchange between the two sides. As the basic exchange of information, gossip and therefore attention becomes more affordable, one would expect that individuals do not drop contacts, but maintain them using the available telecommunication channels, but also using the possibilities to multiply messages nearly freely employing for example the cc - line of the email system, a professional mailing list, or xerox copies of newsletters. See also Burt, 2000a.

On the other side it is unlikely that the ability to co-ordinate a network grows at the same rate as the exponentially growing number of potential interactions within a growing network, one would therefore expect as a corollary, that

[2.1] Individuals will belong to more networks as the number of active contacts grows 
This is consistent with Dunbar's (1992) suggestion that membership of social groups (networks) have upper limits, as they splinter when the time needed for the social grooming essential for its coherence becomes prohibitive. It is also consistent with the group size scaling laws proposed in Zhou, Sornette, Hill and Dunbar (2005).

The distribution of the increasing number of contacts in an increasing number of networks can be accommodated by different topologies, in particular with different link densities (counting here links between the same persons separately, if they arise from different contexts and networks, such as work, church, sport club, card playing round). Given the implied co-ordination effort, one would expect with the third hypothesis:

[3] The probability of being linked to a member of one's network through multiple networks increases with the spatial density of one's contacts

This drop in the spatial social (network) density should reduce the casual social supervision of the local environment, as it contains fewer known and therefore significant others. Jane Jacob’s (1961) “eyes on street” disappear for lack of interest. See Watts and Strogatz, 1998; Newman, 2001 or Girvan and Newman, 2002 for empirical measurement of such clustering in non-localised professional contexts.

Even with longer life spans and lower average working hours the 24 hour time constraint remains in the short-run and therefore as a limitation on individuals in the management of their social networks through the allocation of time and other resources; implicitly time for those dependent on their wages. While the absolute size of the number of social contacts has received substantial attention (see example Pool and Kochen, 1978; Bernard, Johnsen, Killworth and Robinson (1987); Grierson, Smith and Wain (2003); Van Tilburg (1995); McCarty, Bernard, Killworth, Shelley and Johnsen (1997) or Zheng, Salganikz and Gelman (2005)), the distribution of the effort among these contacts seems to have received less attention. From a transport perspective this information is crucial, as it is correlated with the likelihood of travel. While time budget studies could provide such information, they do not, as they neither identify individuals contacted, visited or spoken to nor cover enough days for a reliable estimate. Indirect measures, such as visiting frequency by type of contact, provide some insight, but they omit detailed information about other forms of contact. The person survey of 2003 Thurgau diary asked the respondents to nominate up to 5 relatives and up to 5 other important contacts and to specify both the meeting frequency and their home location. Using the crowfly distance between the home locations of the respondents and their contacts one can estimate the effort by approximating it with the distance travelled (Figure 7) and the distribution of total effort, here for the sample as a whole (Figure 8) 
Figure 7 Median distance between home locations by type of relationship and frequency of visit (2003 Thurgau survey)

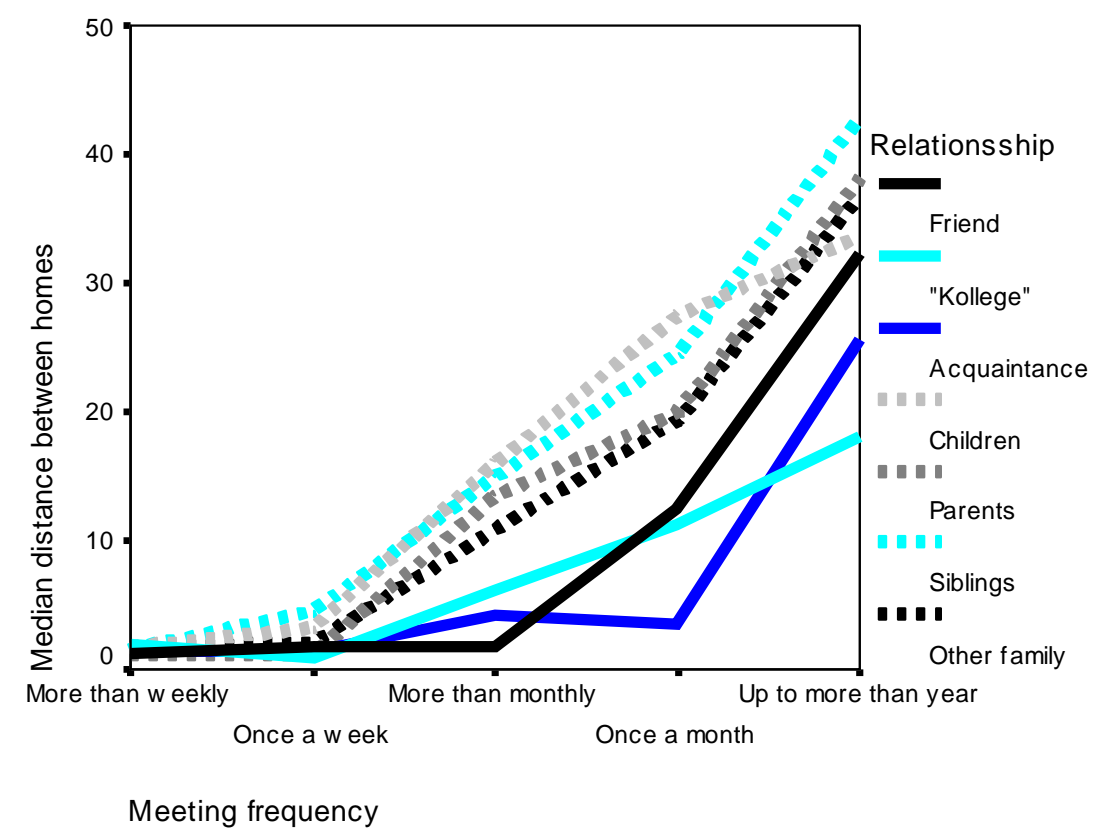

Note that "Kollege" in Swiss-German is a term covering everybody from work mate, school mate, fellow member of a sports clubs, fellow soldier to somebody who is more than just an acquaintance; Note as well, that it is well known, that people overestimate the frequency of rare events.

It is likely that not only the distribution of this crude proxy is left skewed, but also the true distribution of effort among the social contacts, in particular if one considers, that the household members are missing in this data set. Hypothesis four is:

[4] The distribution of effort on non-household members will become more left skewed as the spatial social network tightness decreases

A socially tightly knit local environment provides a large amount of information about contacts and contacts of contacts. It affords the opportunity to meet others without scheduling the meeting, as one knows where one is likely to meet another person, quite independently of random meetings, which will also occur more frequently when using the same small and shared environment. This density of information means that the other often does not need to explain much to sketch a situation or problem. This information externality is lost when the local social tightness is reduced and requires contacts to spend more time on updating the other about everyday details, which form the background of any larger issue. Together with the stronger selectivity mentioned above, it is likely that most persons will reallocate time and resources to maintain a certain quality of interaction with their most important contacts leading to the 
stipulated shift. The lower costs involved in maintaining contacts with the lower ranked contacts supports this shift as well.

Figure 8 Distribution of total effort by category of effort (kilometres travelled per year) in the 2003 Thurgau survey

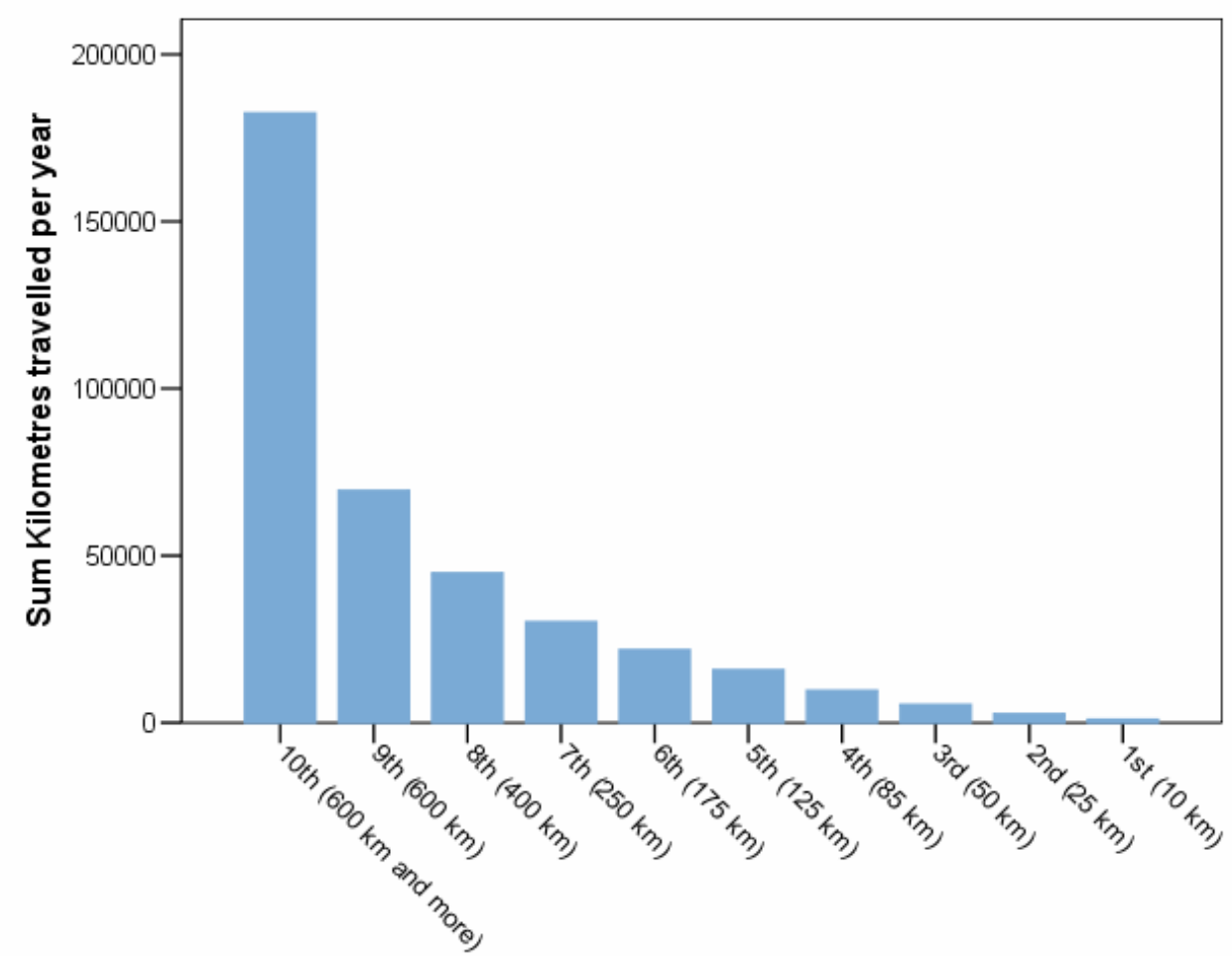

Note that the effort distribution was divided in deciles; the labels are approximate

In a spatially dense and therefore strongly overlapping set of social networks it is likely that members know about the contacts of their contacts, even if these are not part of their own social network. The stipulated shift in the distribution of effort and in the local density leads therefore to hypothesis five:

[5] The knowledge about the contacts of contacts in a social network is proportional to the generalised costs of travel and communication

This change, if true, has the externality, that the efficiency of the network to spread information, gossip or rumour locally is reduced. It has also the corollary, that

[5.1] The distance decay of the social supervision is less steep in spatially looser sets of networks 
If a set of social networks is spatially well defined, then its members know when they have left its territory, left the range of supervision. The "dirty weekend in Brighton" reflected that distance in Victorian Britain. If sets of networks are spatially less well defined, and more spread out, the chance increases to meet a friend of a friend, of whom one had not been aware, further away from home. This should be true not only in the spatial sense, but also in the sense of social distance.

Social milieus reinforce this effect. Social milieu can be understood as the voluntary recreation of the large world of high generalised costs of travel through understood sets of meeting points and common events. The type, style and combinations of meeting points and common events differ between milieus; e.g. university professors of a discipline will have for example joint conferences, preferred institutions for sabbaticals, typical clients and derived from these locations for other professional and informal meetings (holiday locations around conference locations; restaurants around the offices of important clients, etc.). This is reinforced through the common preference for non-professional activities given an often shared habitus in Bourdieu's (1984) sense. As a person belonging to a milieu is likely to frequent these common meeting points at anywhere it finds itself, the likelihood increases for the person that he/she will and can connect with friends of friends, or formulated negatively reports about behaviour away from home will reach home quickly. The mobile phone reinforces this through its recreation of a common locality through the web of SMS, chat and talk.

The mobile phone (Geser, 2005) makes milieus (social networks) without fixed locations and events possible, as the coordination can be achieved on the move. The substantial and sophisticated coordination performances around recent anti-globalisation events are good examples of these possibilities.

These structures of encounterability ${ }^{2}$, of who is likely to be where, when, with whom, are known or can be identified using established clues for different milieus, in particular if they have formed into defined subcultures, such as those around religious affiliation, political belief, diasporas or sexual orientation. Modern creations, such as alumni networks, fan clubs, etc., add these structures of predictability in a world, which appears locally socially unstructured.

\footnotetext{
${ }^{2}$ Margaret Grieco suggested this concept during discussions in the course of the Dft - funded project "Social networks and future mobilities: 'Meetings' in the twenty-first century"
} 
In addition, such structures are constructed for further subgroups of the population through their joint scheduling necessities or infrastructure use: think of parents of a particular type or aspiration congregating at the end of the school day at the relevant school; consider the commuters' time-space paths bundled into the same train and carriage through the railway timetable for a specific origin and destination.

If social network geographies and social network structures behave as stipulated in the hypotheses and collaries discussed above, then this should have impacts on travel behaviour, the level of local trust and the welfare of the individuals. The increased geographies require more travel in terms of miles or kilometres travelled, as personal meetings remain essential to the coherence and development of a network for the time being (Urry, 2000 and 2003). The distances involved for these meetings will sustain a demand for high-speed travel, which in turn can become more efficient exploiting economies of scale and scope; here larger airplanes and more routes/lines. Furthermore, the social network geography is linked to the activity space, i.e. the geography of daily travel, in the sixth hypothesis:

[6] The activity space of an individual is proportional to its social network geography

The action space, i.e. the geography of locations known to a person, will grow even faster, as the increasing spatial spread and increasing number of contacts will combine to raise awareness of yet not visited locations. This trend is overlaid with the aging of the individual, who is accumulating information over his/her lifetime. The attitudes towards travel, communication and openness towards others and other things (variety seeking) are influenced by the experiences during childhood and youth of an individual (see Dienel, Meier-Dallach and Schröder, 2004 for an initial exploration of these links). We would expect therefore correlations between the activity space and social network geographies between generations. This is an additional effect beyond that part of the parental social network which an individual inherits from his or her parents.

Finally, while the action space continues to grow (Hypothesis seven),

[7a] The size of the local activity space of an individual stabilises after an initial exploration.

[7b] The size of the total activity space will grow in line with the growth of social network geographies. 
New locations will tend to be further away from the home location than previously visited locations, as likelihood of finding a new location is larger outside the existing range. Their small share of all locations shifts the footprint from months to months. Still, there should be an equilibrium size, when the rate of turnover and change inside the activity space produces enough new locations to satisfy the variety seeking of the individual. The size of the total activity space will grow in line with the growth of social network geographies over longer periods.

The reduction in the number of interested "eyes on the street" and the reduction in the local tightness of network links should result in increased feelings of insecurity, independent of the actual number of crimes. The environment becomes increasingly socially empty and therefore less trustworthy (see Seligman, 2000 for the problem of social trust). Localised anomie in a society which is still well integrated at larger scales should become more frequent (Franzen, 2000). (See Axhausen, 2000 for a review of the recent critique of suburbanisation, which is partially based on these fears).

This contrast between the local and non-local comes to the fore in times of crisis, whether for serious cases such as illness or accidents, supervision of children or elderly relatives, but also for trivial cases, such as the care of potted plants or the emptying of a letter box during a prolonged absence. Hypothesis eight is, that

[8] The reliance on commercial or publicly funded personal services increases proportionally with the geography of social networks

as services traditionally traded or undertaken in local social networks cannot be secured anymore due to the lower densities of contacts. The commercialisation of such services produces different patterns of stress for their users, as a) time gets traded against money, which needs to be earned (see Becker, 1976), and b) as some form of supervision is still required due to the possible unreliability or incompetence of such services.

Finally, the social selectivity possible in a world of cheap travel and telecommunication should result in social more homogenous networks (See also the review of McPherson, SmithLovin and Cook, 2001). These in turn should become more productive for their members (See Galor and Weil, 2000 for the economic success inherent in specialisation and increases in the economies of scale). The balance between social and psychological challenge and reinforcement can be set by each individual through the range of networks to which it belongs. Those networks, which are not constructed according to such Wahlverwandschaften (elective affini- 
ties), i.e. family, and less so work, church, profession, should become less important and come under increasing stress. All told, hypothesis nine is, that on balance

[9] the welfare of the individuals should increase inversely proportional to the generalised costs of travel

as they have more control over their social context, even accounting for the costs identified above. See Frey and Stutzer, 2001 and Layard, 2005 for a contrasting view. One question though is how the costs of the local anomie are distributed between different strata of the population. The world of low generalised travel costs still favours the wealthier, which can respond easier to unwelcome change through the exercise of their exit option. The strength of the local organised voice option in the pursuit of the management, redirection or reversal of such change is likely to be weaker as a result. Equally, the number of weak ties in Granovetter's (1973) sense is likely to be reduced for persons who are relatively more bound to the locality. While much of the factual information formerly brokered by the weak ties can be found today in electronic forms, the essential qualitative assessment of the information and the sponsorship available from the weak ties is reduced.

\section{A qualitative model of social networks and activity space}

The hypotheses suggested above stand alone and are not linked to other choices an individual makes. Ignoring the biographical dimension, Figure 9 suggests a quasi-static model linking individual choices to the size of individual activity space and the structure and geography of the personal social networks. It indicates the sign of the elasticities, but not their size. Microeconomic theory suggests that the individual can increase his wages by specialization or by increasing the number of hours worked. Investment into the level of specialization through education and further training is deemed to be the better long term strategy, which is not only adopted by individual families, but also as national policy by most countries around the world. A condition for successful specialization is that the labour market has to be large enough to offer a relevant post or posts. From an individual's point of view specialisation requires more often than not either migration or long commutes, which in turn are easier if the generalised costs of travel and communication are small. 
Figure 9 Expanded qualitative model of social networks and activity space

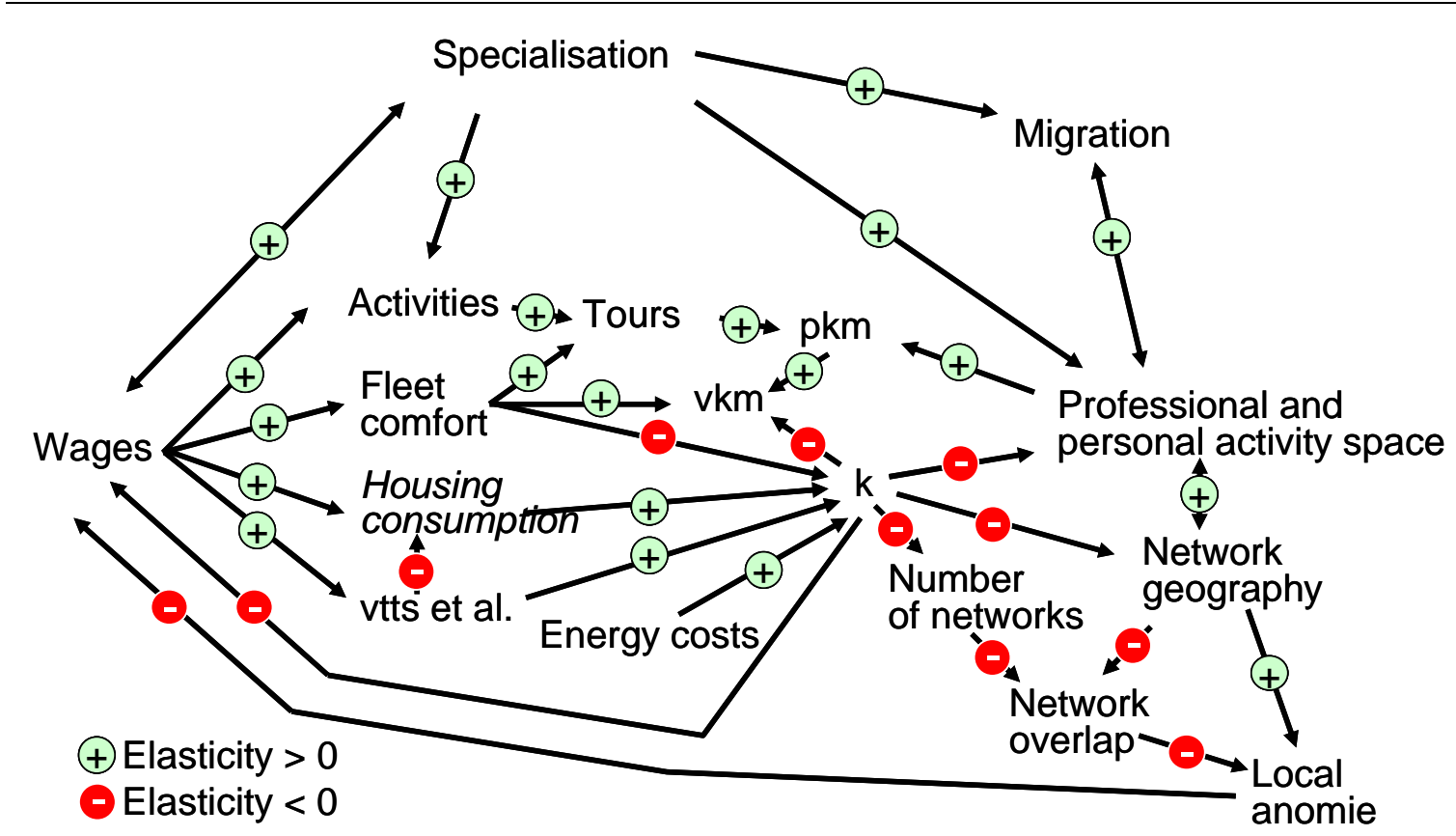

k: Generalised costs of travel (and communication); pkm: Personal km; vkm: Vehicle km; vtts: Value of travel time savings; fleet comfort: number and standard of the personal mobility tools, i.e. cycles, cars, trucks and public transport season tickets;

While all consumer goods are elastic with respect to income and wages, the model focuses on those important for travel behaviour. Increases in wages do encourage out of home activity, as does the division of labour inherent in specialisation, even if these effects will be small with respect to the number of trips undertaken. The income elasticities of housing consumption and fleet comfort are known to be substantial (see for example Rumley, 1984; Hanly, Dargay and Goodwin, 2002; Fogel, 2002; Barker, 2003 or Barot and Yang, 2002). The central point about the vehicle fleet or more generally the set of mobility tools (cycle, motorcycle, car, SUV, season ticket, public transport season tickets - transit passes), which a person acquires, is that lump sum payments are exchanged for lower variable costs. A private car allows the owner to avoid the lower speed and lower flexibility of public transport or the higher variable cost of a taxi ride. All public transport rides are free (at the point of use) for the season ticket holder.

The willingness to pay for lower travel times, better higher speeds, more comfort and more reliability are known to be elastic to income (see for example König, Abay and Axhausen, 2004 or Fosgerau, 2005), which increases the generalised costs of travel under ceteris paribus conditions. The same is generally also true for increased housing consumption, as this normally requires locations further from the denser parts of an urbanised area. Still, unless collective choices keep capacities or slots for movement very tight, one would expect that in sum the in- 
dividual is able to lower the generalised costs of travel, which implicitly increases its wages (See Cervero and Hanson (2002) or Levinson and Karamalaputi (2003) for highway network supply elasticities)

The model in its lower right hand side then summarises the hypotheses discussed above, while removing some detail for clarity. This detail is added in Figure 10

Figure 10 Hypotheses summarised

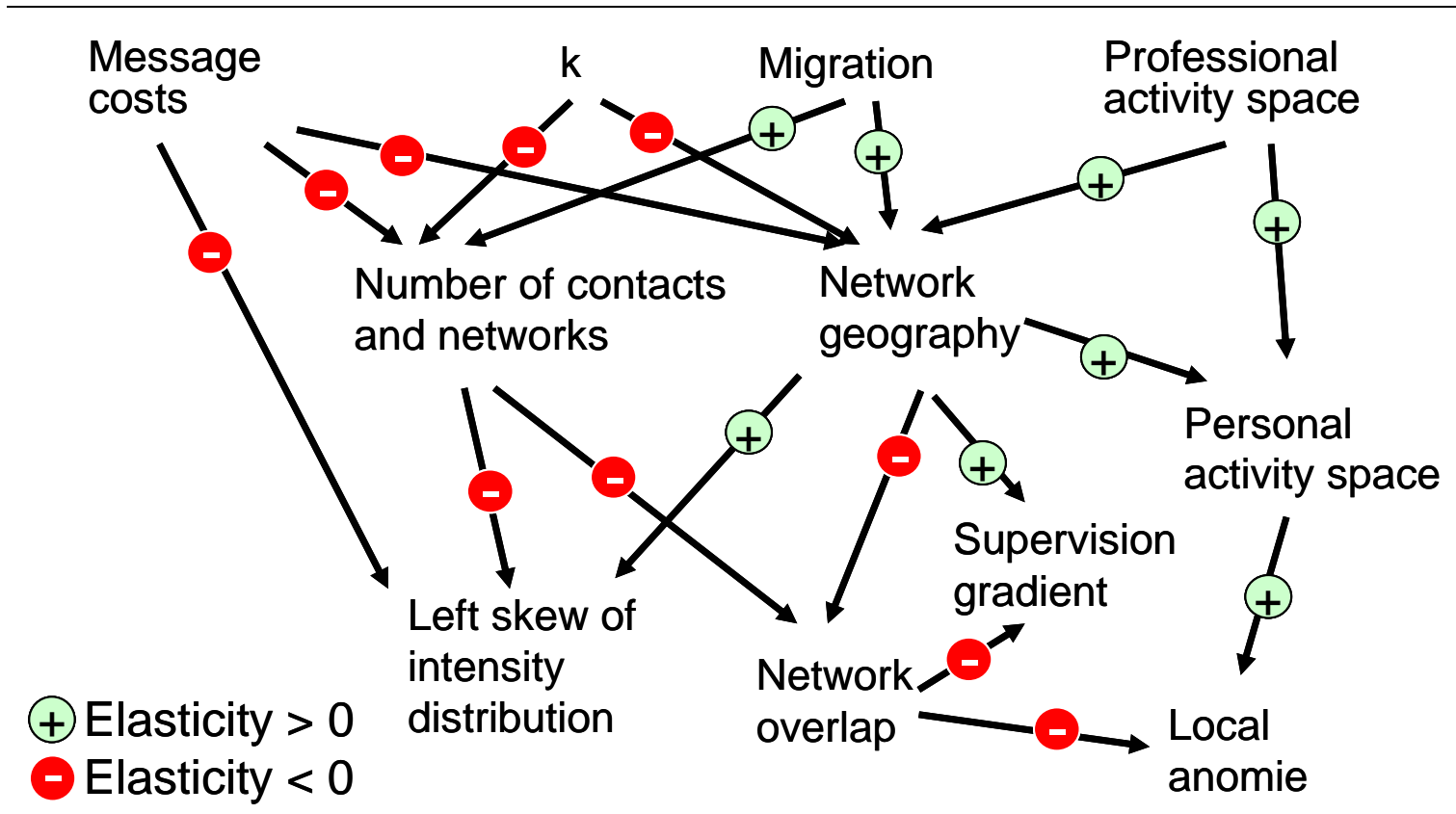

k: Generalised costs of travel

It is interesting to note that the growth in vehicle kilometres driven is sustained through three mechanisms as long as real incomes rise: increased fleet comfort, increased housing consumption, lower generalised costs of travel and increased activity spaces, such as those shown in Figure 6. The monetary and social investment in these areas makes it likely that the process is not easy to reverse once under way. A hysterisis like pattern is likely to emerge due to the social capital inherent in the networks, such as common understandings, trained ability for successful joint performance, co-evolution of skills or joint history (See also Lin, 2001; Sobel, 2002; Grieco, 1988).

Having assumed throughout, that the observed and stipulated processes go hand in hand with increased levels of personal welfare, the model also explains the on-going dissolution of the local social coherence typical for a world of high generalised costs of travel and communication. In that world individuals were linked to each other through multiple contexts and were 
likely to meet each other regularly - planned or by chance (Tönnies, 1887 - reprint 1935). The last decades can only be described as a flight from this environment for most people (Putnam, 1999), who seem on average to prefer a spatially less tight social environment. Still, some groups never wanted to leave, such as orthodox Jews tied to their synagogue or the Amish tied to their community by the refusal to use cars; other people wanting to recreate it in parts by buying into gated communities (Low, 2003 or Blakely and Snyders, 1997) or new urbanist environments, which help to identify others with the wish to live a more local life; some people were not able to leave, as they did not have and still do not have the resources to do so. Manifold problems arise for the last type of people, as they have to live in an expensive small world, when the rest of the world assumes that it is a low cost world, which is driven by the processes sketched in Figure 11, which are structurally parallel to the model of individual activity spaces suggested above.

Figure 11 Qualitative model of market size for goods and services

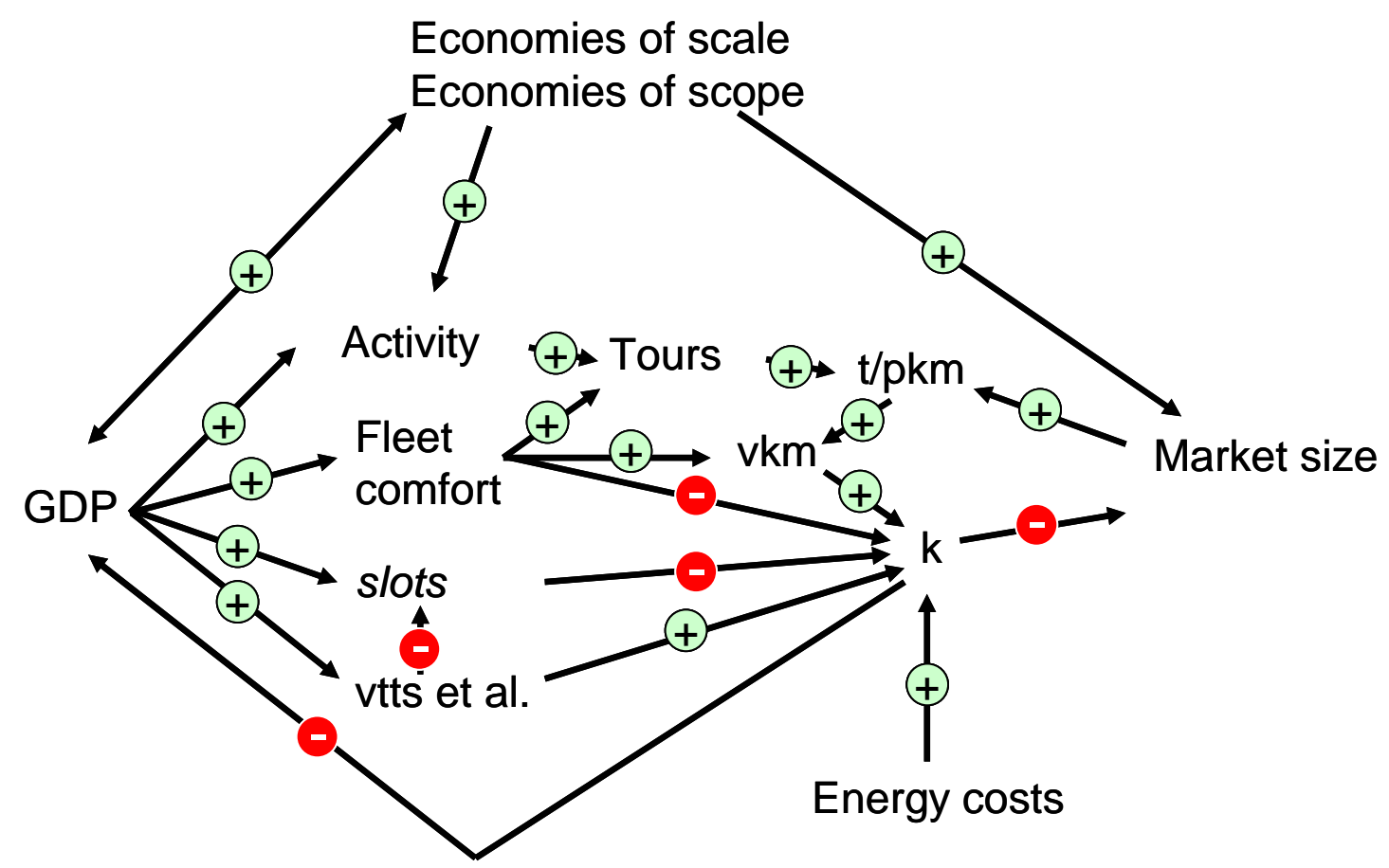

k: Generalised costs of travel; slot: Time-space window allocated to a movement on the available infrastructure or the services operated on them; vtts: Value of travel time savings

\section{Research questions}

The qualitative models and the hypotheses formulated above form a research programme as many of the stipulated links and effects have not been empirically demonstrated yet. There are 
three areas of urgent work at this point: solving the measurement problems, estimating the behavioural elasticities and understanding the links between social welfare, localised anomie and the size of the activity spaces.

There are various approaches to obtain a complete or nearly complete view of the set of contacts of an individual. Diaries can be supplemented by personal telephone books, email directories, telephone bills, photo albums, year books, roosters of the clubs and associations, internal phone books of employers etc. In addition, various tests based on name recognition can be constructed. While such work is challenging enough, the real challenge is the reconstruction of past patterns, as the persons need to remember where their contacts lived at a particular time.

Current surveys show that respondents in face-to-face interviews are willing and able to reconstruct their mobility biography and their network of important contacts over time (See Ohnmacht, 2004 and ongoing work at Lancaster with respondent which were recruited using a substantial incentive payment (75 SFr (50€) or $20 £$ ). A recent paper-and-pencil survey involving a complex matrix representation of time and items (homes, workplaces, mobility tools) resulted in good quality responses, but a low response rate. In neither case have the answers of the respondents' been validated independently using official records or third parties.

This issue of validation is even more important for retrospective answers, as few people will have retained their address books over the years. The switch to electronic data bases makes such personal record keeping even less likely in the future.

One central research area is therefore the development of reliable and cost-efficient methods to record and reconstruct the social network geographies. Validation of the respondents' answers through either official or written records or snowball sampling of the identified contacts will need to be explored.

The available methods for tracing the daily activity space, diaries, but in particular satellite positioning systems and mobile phone records are proven, even if in need of fine tuning. Here the issue is the reconstruction of past activity spaces from respondents' recollections. There is a need to test new approaches, as current efforts using a small number of supposedly key locations have not been successful so far.

The models and the hypotheses above suggest the behavioural system responds to changes in the structure of the generalised costs. Some of these elasticities are known (for some coun- 
tries), but many are not, in particular those concerning the structure and geographies of the social networks and linked with them of the activity spaces. While these estimates would be interesting in their own right, they are especially important for transport policy making. Much of the policy discussion in transport is focusing on increasing the generalised costs of travel in line with the external costs of travel and sometimes beyond. If the hypotheses presented here are correct, it is unlikely that the adjustment of the individuals will be fast due to the investment into the contacts behind the travel, nor politically easy to achieve.

The paper has also suggested a further externality of the new social network geographies: localised anomie due to an under-critical local social network tightness. Transport researchers have addressed this issue obliquely through their interest in the feeling of personal safety while walking, especially to and from public transport stops. In the transport and regional planning literature studies have not linked their results to the local social network structures. The measurement problem is substantial as both the feeling of safety under different conditions and the local social network tightness have to be established. If the link can be established, then the question remains, if this externality should be addressed socially and if so how, or if the personal responses of exit (moving away) and individual protection (fortifying the residence and the use of motorised personal and protected spaces (cars)) are appropriate. See Brook and Durlauf, 2001 or Durlauf and Cohen-Cole, 2004 for the difficulties of model estimation, when social structure is endogenous to the issue at hand.

In this context one could make use of recent work on the general happiness of a population to see, if some of the variation of the level of happiness can be explained by the structure and geographies of the social networks (see for example Layard, 2005, Stutzer and Frey, 2004 or Frey and Stutzer, 2001). Making this link would allow us to see, if continuing private and social investment in lower generalised cost of travel do indeed increase the social welfare further.

\section{Acknowledgements}

This paper develops ideas, which have been presented and discussed on a number of occasions (Axhausen, 2002a, b; 2004a-d; 2005a,b, and in press). The author is grateful for the suggestions and critique, which arose at seminars organised by M. Grieco, Cornell University, Martin Lee-Gosslin, Laval University, Julian Hine, University of Ulster, Fritz Busch, Technische Universität München, Barbara Lenz, DLR, Berlin, Uwe Serkölt, Universität Zürich, 
and Ph. Toint, FUNDP, Namur. The on-going discussions with M. Grieco have shaped this paper in many ways.

The paper has also benefited from the joint project "Social networks and future mobilities: 'Meetings' in the twenty-first century” with J. Urry and J. Larson at the University of Lancaster funded by the Horizons Programme of the UK Department for Transport and with T. Ohnmacht, TU Berlin on "Mobility biographies, mobility tools and social networks" funded by the Institut für Mobilitätsforschung, Berlin.

\section{Literature}

Abay, G. (2000) Preisentwicklung im Personenverkehr, report to the ARE, Abay und Meier, Zürich.

Axhausen, K.W. (2000) Geographies of somewhere: A review of urban literature, Urban Studies, 37 (10) 1849-1864.

Axhausen, K.W. (2002a) A dynamic understanding of travel demand: A sketch, Arbeitsberichte Verkehrs- und Raumplanung, 119, Institut für Verkehrsplanung und Transportsysteme, ETH Zürich, Zürich.

Axhausen, K.W. (2002b) Verkehrsentwicklung, Mobilitätswerkzeuge und soziale Netze: Ein Versuch, presentation at Europäisches Forum Alpbach, Alpbach, August 2002.

Axhausen, K.W. (2004a) Biographien, soziale Netze und Verkehrsverhalten: Hypothesen und erste Ergebnisse, presentation at CIS-Tagung - Anwendung der sozialen Netzwerkanalyse, Universität Zürich, October 2004.

Axhausen, K.W. (2004b) Personal biography, social networks and travel behaviour: Hypotheses and assumptions, presentation at Odyssey Meeting, University of Ulster, Belfast, August 2004.

Axhausen, K.W. (2004c) Stabilität und Innovation der Aktivitätsmuster, presentation at DVWG/DLR Seminar „Zeitverwendung und Mobilität - Die These vom konstanten Zeitbudget“, Berlin, November 2004.

Axhausen, K.W. (2004d) Verkehrsverhalten, Aktivitätenräume und soziale Netze, presentation at the Fortbildungsseminar des Instituts für Verkehrswesen, Universität Karlsruhe, June 2004.

Axhausen, K.W. (2005a) Markets, networks and productivity: Some suggestions, presentation at FUNDP, Namur, March 2005.

Axhausen, K.W. (2005b) Wie viel Stadt braucht Herr Müller ? Stabilität, Dynamik und Innovation im Verkehrsverhalten, presentation at the Seminar "Verkehr Aktuell", Deutsches Museum, München, February 2005.

Axhausen, K.W. (In Press) Social networks and travel: Some hypotheses, in K. Donaghy (ed.) Social Aspects of Sustainable Transport: Transatlantic Perspectives, Ashgate, Aldershot.

Axhausen, K.W. and P. Fröhlich (2004) Public investment and accessibility change, in H. Held 
and P. Marti (eds.) Bauen, Bewirtschaften, Erneuern - Gedanken zur Gestaltung der Infrastruktur, 207-224, vdf, Zürich.

Axhausen, K.W., A. Zimmermann, S. Schönfelder, G. Rindsfüser and T. Haupt (2002) Observing the rhythms of daily life: A six-week travel diary, Transportation, 29 (2) 95124.

Axhausen, K.W., S. Beige and M. Bernard (2004) Perspektiven des Schweizerischen Verkehrs bis 2030: Module M04 und M05 Besitz von Mobilitätswerkzeugen Fahrleistungen/Betriebsleistungen und Verkehrsleistungen, Bericht an das ARE, IVT, ETH Zürich, Zürich.

Barabasi, A.L. (2002) Linked: How Everything Is Connected to Everything Else and What It Means, Plume, New York.

Barker, K. (2003) Securing our Future Housing Needs - Review of Housing Supply: Interim Report - Analysis, report to HM Treasury, London ${ }^{3}$.

Barot, B. and Z. Yang (2002) House prices and housing investment in Sweden and the United Kingdom: Econometric analysis for the period 1970 - 1998, Working Paper, 80, National Institute of Economic Research, Stockholm

Beck, U. (1986) Risikogesellschaft, Suhrkamp, Frankfurt.

Becker, G.S. (1976) The Economic Approach to Human Behavior, University of Chicago Press, Chicago.

Bernard, H. R., E.C. Johnsen, P.D. Killworth and S. Robinson (1987) Estimating the size of an average personal network and of an event subpopulation: some empirical results, Proceedings, Americal Statistical Organisation ${ }^{4}$.

Blakely, E. and M.G. Snyders (1997) Fortress America, Brookings Institution, Washington, D.C.

Blinde, J. and R. Schlich (2002) Freizeitmobilität und Wohnsituation, in M. Gather and A. Kagermeier (Hrsg.) Freizeitverkehr, Hintergründe, Probleme Perspektiven, Studien zur Mobilitäts- und Verkehrsforschung, 1, 35-53, Verlag MetaGIS Infosysteme. Mannheim.

Botte, M. (2003) Strukturen des Pendelns in der Schweiz, MSc thesis, Fakultät für Bauingenieurwesen, TU Dresden, August 2003.

Bourdieu, P. (1984) Distinction: A Social Critique of the Judgement of Taste, Harvard University Press, Cambridge.

Brock, W. and S. Durlauf (2001) Discrete Choice with Social Interactions, Review of Economic Studies, 68 (2) 235-260.

Burt, R.S. (2000a) Decay functions, Social Networks, 22 (1) 1-28.

Burt, R.S. (2000b) The network structure of social capital, in R.I. Sutton and B.M. Straw (eds.) Research in Organization Behaviour, 22, JAI Press, Greenwich

Burt, R.S. (2001) Structural holes versus network closure as social capital, in N. Lin, K. Cook and R.S. Burt (eds.) Social Capital: Theory and Research, 31-56, Aldine de Gruyter, New York.

Cervero, R. and M. Hansen (2002) Induced travel demand and induced road investment,

\footnotetext{
${ }^{3}$ http://news.bbc.co.uk/1/shared/spl/hi/uk/03/budget/documents/pdf/barker_review_foretoch3_396.pdf

${ }^{4}$ http://www.amstat.org/sections/srms/Proceedings/papers/1987_003.pdf
} 
Journal of Transport Economics and Policy, 36 (3) 469-490.

Cervero, R. and M. Hansen (2002) Induced travel demand and induced road investment: A simultaneous equation analysis, Journal of Transport and Policy, 36 (3) 469-490.

Dienel, H.L., H.-P. Meier-Dallach and C. Schröder (2004) Raumpartnerschaften verbinden Kontrasträume, Steiner, Stuttgart.

Dodds, P.S., R. Muhamad and D.J Watts (2002) An experimental study of search in global social networks, Science, 301, 827-829.

Dunbar, R.I.M (1992) Neocortex size as a constraint on group size in primates, Journal of Human Evolution, 20 (xx) 469-493.

Durlauf, S. and E. Cohen-Cole (2004) Social interaction models, Working Paper, Economics Department, University of Wisconsin, Madison ${ }^{5}$.

FCC (2001) Long distance telecommunication industry, FCC, Washington, D.C.

Fehr, E. and S. Gächter (2000) Fairness and retaliation: The economics of reciprocity, Journal of Economic Perspectives, 14 (1) 159-181.

Fehr, E. and U. Fischbacher (2004) Social norms and human cooperation, Trends in Cognitive Sciences, 8 (4) 185-190.

Fogel, R.W. (2002) Toward a postmodern egalitarian agenda, paper presented at the Commonwealth North Forum, Anchorage, August 2002

Fosgerau. M. (2005) Unit income elasticity of the VTTS, paper presented at the $8^{\text {th }}$ Nectar Conference, Las Palmas, June 2005.

Franzen, A. (2000) Does the Internet make us lonely ?, European Sociological Review, 16 (4) 427-438.

Freeman, L.C. (2000) Social Network Analysis: Definition and History, in A. E. Kazdan (ed.) Encyclopedia of Psychology, 6, 350-351, Oxford University Press, New York.

Frei, A. (2005) Was hätte man 1960 für einen Sharan bezahlt?, MSc Thesis, Department Bau, Umwelt und Geomatik, ETH Zürich, Zürich.

Frey, B.S. and A. Stutzer (2001) Happiness and Economics: How the Economy and Institutions Affect Human Well-Being, Princeton University Press, Princeton.

Friedman, T.L. (2005) The World Is Flat: A Brief History of the Twenty-First Century, Farrar, Straus and Giroux, New York.

Fröhlich, P. (2003) Induced traffic: Review of the explanatory models, paper presented at the 3rd Swiss Transport Research Conference, Ascona, March 2003.

Galor, O. and D.N. Weil (2000) Population, technology, and growth: From Malthusian stagnation to the demographic transition and beyond, American Economic Review, 90 (4) 806-828.

Geser, H. (2004) Towards a sociological theory of the mobile phone, Version 3, Soziologisches Institut, Universität Zürich, Zürich.

Giddens, A. (1984) The Constitution of Society, Polity Press, Cambridge.

Girvan, M. and M.E.J. Newman (2002) Community structure in social and biological networks, Proceedings of the National Academy of Sciences of the USA, 99 (12) 7821-7826.

\footnotetext{
${ }^{5}$ http://www.ssc.wisc.edu/econ/Durlauf/research.html
} 
Goffman, E. (1959) The Presentation of Self in Everyday Life, Anchor Books, New York.

Granovetter, M. (1973) The strength of weak ties, American Journal of Sociology, 78 (6) 13601380.

Grieco, M.S. (1988) Keeping It in the Family: Social Networks and Employment Chance, Tavistock Publications, London.

Grieco, M.S. (1996) Workers' Dilemmas: Recruitment, Reliability and Repeated Exchange, Routledge, London.

Grierson, J., A. Smith and D. Wain (2003) Victorian Networks Study: Technical Report Method, Sample and Preliminary Findings, Latrobe University, Melbourne.

Grübler, A. (1990) The rise and fall of infrastructure: Dynamics of evolution and technological change in transport, Physica-Verlag, Heidelberg.

Grübler, A. (1998) Technology and Global Change, Cambridge University Press, Cambridge.

Hampton, K.N. and B. Wellman (2001) Long distance community in the network society: Contact and support beyond Netville, American Behavioral Scientist, 45 (3) 477-96.

Hamtpon, K.N. and B. Wellman (2003) Neighbouring in Netville, City \& Community, 2 (4) 277-311.

Hanly, M., J. Dargay and P. Goodwin (2002) Review of Income and Price Elasticities in the Demand for Road Traffic, report to the DfT, ESRC TSU Publications, 2002/13, UCL, London.

Haythornwaite, C. and B. Wellman (1998) Work, Friendship, and Media Use for Information Exchange in a Networked Organization, Journal of the American Society for Information Science. 49 (12) 1101-1114, 1998.

Huberman, B.A. and L.A. Adamic (2005) Information dynamics in the networked world, Working Paper, HP Laboratories, Palo Alto.

Jacobs, J. (1961) The Death and Life of Great American Cities, Vintage, New York.

Layard, R. (2005) Happiness, Penguin, London.

Levinson, D. and R. Karamalaputi (2003) Induced supply: A model of highway network expansion at the microscopic level, Journal of Transport Economics and Policy, 37 (3) 297-318.

Lin, N. (2001) Building a network theory of social capital, in N. Lin, K. Cook and R.S. Burt (eds.) Social Capital: Theory and Research, 3-29, Aldine de Gruyter, New York.

Low, S.M. (2003) Behind the Gates: The New American Dream, Routledge, London.

McCarty, C., H.R. Bernard, P.D. Killworth, G.A. Shelley and E.C. Johnsen (1997) Eliciting representative samples of personal networks, Social Networks, 19 (3) 303-323.

McPherson, J.M, L. Smith-Lovin and J. Cook (2001) Birds of a Feather: Homophily in Social Networks, Annual Review of Sociology, 27, 415-444.

Milgram, S. (1967) The small world problem, Psychology Today, 2 (1)60-67

Moore, E.G. and L.A. Brown (1970) Urban acquaintance fields: An evaluation of a spatial model, Environment and Planning, 2 (4) 443-454.

Newman, M.E.J. (2001) The structure of scientific collaboration networks, Proceedings of the National Academy of Sciences of the USA, 98 (2) 404-409.

Newman, M.E.J., D.J. Watts and S.H. Strogatz (2002) Random graph models of social networks, Proceedings of the National Academy of Sciences of the USA, 99 (1) 2566- 
2572, February, 2004.

Ohnmacht, T. (2004) Soziale Netze und persönliche Mobilität: Grundlagen für eine empirische Erhebung, Arbeitsbericht Verkehrs- und Raumplanung, 250, IVT, ETH Zürich, Zürich.

Pool, I. and M. Kochen (1978) Contacts and influence, Social Networks, 1 (1) 5-51.

Putnam, R.D. (1999) Bowling Alone: The Collapse and Revival of American Community, Schuster and Schuster, New York.

Raff, D.M.G. and M. Trajtenberg (1995) Quality-adjusted prices for the American automobile industry: 1906-1940, Working Paper, 5032, National Bureau of Economic Research, Cambridge.

Rhode, P.W. and K.S. Strumpf (2003) Assessing the importance of Tiebout sorting: Local heterogeneity from 1850 to 1990, American Economic Review, 93 (5) 1648-1677.

Rumley, P.A. (1984) Amenagement du territoire et utlisation du sol, Dissertation, ORL, ETH Zürich, Zürich.

Schäfer, A. And D.G. Victor (2000) The future mobility of the world population, Transportation Research, 34A (3) 171-205.

Scherer, M. (2004) Erreichbarkeitsveränderungen in der Schweiz: Eine kartographische Darstellung, term paper, IVT, ETH Zürich, Zürich.

Schönfelder, S. and K.W. Axhausen (2003a) On the variability of human activity spaces, in M. Koll-Schretzenmayr, M. Keiner and G. Nussbaumer (eds.) The Real and Virtual Worlds of Spatial Planning, 237-262, Springer, Heidelberg.

Schönfelder, S. and K.W. Axhausen (2003b) Activity spaces: Measures of social exclusion ?, Transport Policy, 10 (4) 273-286.

Seligman, A.B. (2000) The Problem of Trust, Princeton University Press, Princeton.

Sen, A. (1983) Poverty and Famines: An Essay on Entitlement and Deprivation, Oxford University Press, Oxford.

Sobel, J. (2002) Can we trust social capital ?, Journal of Economic Literature, 40 (2) 139-154.

Spufford, P. (2002) Power and Profit: The Merchant in Medieval Europe, Thames \& Hudson Ltd, London.

Stutzer, A. and B.S. Frey (2004) Stress that doesn't pay: The commuting paradox, IZA Discussion Papers, 1278, Institute for the Study of Labor, Bonn

Taylor, P.J. (2004) World city network. A global urban analysis, Routledge, London.

Tönnies, F. (1935) Gemeinschaft und Gesellschaft: Grundbegriffen der reinen Soziologie, $8^{\text {th }}$ edition, Wissenschaftliche Buchgesellschaft, Darmstadt.

Travers, J. and S. Milgram (1969) An experimental study of the small world problem, Sociometry, 32 (4) 425-443.

Tschopp, M., P. Fröhlich and K. W. Axhausen (2004) Accessibility and spatial development in Switzerland during the last 50 years: A multilevel regression approach, Arbeitsberichte Verkehr- und Raumplanung, 260, Institut für Verkehrsplanung und Transportsysteme (IVT), ETH Zürich, Zürich.

Tschopp, M., R. Sieber, P. Keller and K.W. Axhausen (2003) Demographie und Raum in der Schweiz, DISP, 153, 25-32.

Urry, J. (2000) Sociology beyond Societies: Mobilities for Twenty First Century, Routledge, London. 
Urry, J. (2003) Social networks, travel and talk, British Journal of Sociology, 54 (2) 155-175.

van Tilburg, T.G. (1995) Delineation of the social network and differences in network size, in C.P.M. Knipscheer, J. de Jong Gierveld, T.G. van Tilburg and P.A. Dykstra (eds.) Living Arrangements and Social Networks of Older Adults, 83-96, VU University Press, Amsterdam.

Verhoeven, M., T. Arentze, H.J.P. Timmermans and P. van der Waerden (2004) Modeling the impact of key events on long-term transport mode choice decisions: A decision network approach using event history data, paper presented at the 84th Annual Transportation Research Board meeting, Washington, Janaury 2005.

Vries, J de and A. Van der Woude (1997) The First Modern Economy: Success, Failure, and Perseverance of the Dutch Economy, 1500-1815, Cambridge University Press, Cambridge.

Wasserman, S. and K. Faust (1994) Social Network Analysis: Methods and Applications, Cambridge University Press, New York.

Watts, D.J. (1999) Small Worlds: The Dynamics of Networks between Order and Randomness, Princeton University Press, Princeton.

Watts, D.J. and S.H. Strogatz (1998) Collective dynamics of 'small-world' networks, Nature, 393, 440-442.

Wellman, B. (1996) Are personal communities local ? A dumptarian reconsideration, Social Networks, 18 (4) 347-354.

Wellman, B. (1999a) Networks in the Global Village, Westview Press, Boulder.

Wellman, B. (1999b) The network community: An introduction, in B. Wellman (ed.) Networks in the Global Village, 1-48, Westview Press, Boulder.

Wellman, B. (2000) Changing connectivity: A future history of Y2.03K, Sociological Research Online, 4 (4), http://www.socresonline.org.uk/4/4/wellman.html

Wellman, B. (2001) The Persistence and transformation of community: From neighbourhood groups to social networks, report to the Law Commission of Canada, Toronto.

Widmer, J.P. and K. Meister (2005) Ausgewählte Schweizer Zeitreihen zur Verkehrsentwicklung, Materialien zur Vorlesung Verkehrsplanung, 1, IVT, ETH Zürich, Zürich.

Zahavi, Y. and A. Talvitie (1980) Regularities in travel time and money expenditures, Transportation Research Record, 750, 13-19.

Zheng, T., M.L. Salganikz and A. Gelman (2005) How many people do you know in prison?: Using overdispersion in count data to estimate social structure in networks, Collective Dynamics Group, Columbia University, New York.

Zhou, W.-X., D. Sornette, R.A. Hill and R.I.M. Dunbar (2005) Discrete Hierarchical organization of social group sizes, Proceedings of the Royal Society, 272B, 439-444. 